\title{
EFFECT OF SHORT TERM EXPOSURE OF EGGS TO MAGNETIC FIELD IN HATCHABILITY AND PRODUCTIVE PERFORMANCE OF PROGENY
}

\author{
Duried Th. Younis \\ Ahmed M.TH. Qasim \\ Animal Production Dept., College of Agriculture and Forestry, University \\ of Mosul, Iraq \\ Emaildr.duraid@uomosul.edu.iq
}

\begin{abstract}
The aim of this study was to identify the effect of exposing broiler breeders eggs to magnetic field before hatching on hatchability and productive performance of progeny. In this research, 300 fertile eggs produced by breeders of Ross 308 were used. they were divided into four Treatments (Seventy-five eggs for each) The Eggs were treated as follows: $\mathrm{T}^{1}$ Control not exposed to magnetic field, $\mathrm{T}^{2}$ eggs exposed to magnetic field 1800 Gauss for 30 minutes, $T^{3}$ eggs exposed to magnetic field 1800 Gauss for 60 minutes, $T^{4}$ eggs exposed to magnetic field 1800 Gauss for 90 minutes. After hatching chicks reared under normal condition in semi opened house until 42 days of age. Statistical data analysis revealed that exposure of the eggs to the magnetic field for 30 minutes induces a substantial increase $(p \leq 0.05)$ in the percentage of hatchability, live body weight, total weight gain, dressing percentage, output index, W.B.C., R.B.C., P.C.V., hemoglobin and blood glucose, also, a decline in mortality of fetuses and variation in feed conversion between treatments.
\end{abstract}

Keywords: magnetic field, Breeders eggs, Hatchability, Productive performance.

Received: 10 / 12 / 2020, Accepted: 13 / 3 / 2021

\section{INTRODUCTION}

The technique of exposing the hatching eggs to the magnetic field is considered one of the future techniques to produce healthy chicks. The employment of magnetic science in medical and health will take place in future because it is inspired from nature which called (friend of nature) and have no side effect as compared with chemical drugs or toxic industrial materials (Al-Mosely,2013). and have the ability to improve the physical properties of water of egg which equal (65-70)\% . Exposing the egg to magnetic field increase the surface area of water which cause an increase the solubility and diffusion which help to increase nutrient transfer, toxic absorption and reduce water tension surface (young and Lee, 2005). Magnetism affects the adhesion angle between the hydrogen and oxygen atoms of the water, which lowers it from $105^{\circ}$ or $104^{\circ}$ to 103 , thus reducing the number of water molecules to form clusters to 6-7 instead of 1012-216 molecules per cluster, and this allows the transport carrying and absorption of nutrients. It passes through cell walls and membranes easily so cells remain more tender (Remedy, 2006). and when this weak current circle in the blood, it increases the amount of ions (which are particles of substances that are charged with an electrical charge due

The research is part of Ph.D. of second researcher 
to a decrease or an increase in electrons) and this ionized blood circulates in the body cause increase the movement of hemoglobin in the blood vessels, which leads to a decrease in the proportion of calcium, Cholesterol and even waste products suspended on the surfaces of blood vessels (Tischler, 2003; and Rokicki, 2006).

\section{MATERIALS AND METHODS}

The current study was performed in the animal production department, college of agriculture and forestry for a period from 6 February until 17 April 2020. Three hundred fertile eggs of broiler breeders hens Ross 308 were used in this study with average weight $58 \mathrm{gm}$. they were divided to four Treatments (Seventy five eggs for each) The Eggs were treated as follows: $\mathrm{T}^{1}$ control no exposing, $\mathrm{T}^{2}$ exposing the eggs to magnetic field 1800 Gauss for 30 minutes, $T^{3}$ exposing the eggs to magnetic field 1800 Gauss for 60 minutes, $\mathrm{T}^{4}$ exposing the eggs to magnetic field 1800 Gauss for 90 minutes, before incubation then eggs incubated for 21 days, after hatching chicks reared under normal condition in semi opened house until 42 days of age. Two hundred forty of hatched chicks distributed to four treatments (sixty chicks for each treatments) divided to three replicate with twenty chicks for each reared in semi opened house. Birds fed two ration Starter for a period one day to 28 days and Finisher from 29 days till age of marketing 42 days. Feed and Water Were ad libitum. At the age of marketing (6 weeks) 2 birds from each replicate weighted and slaughter to calculate dressing percentage and blood collecting to determine red blood cells (R.B.C.), white blood cells (W.B.C.), packed cell volume (P.C.V.), blood glucose and hemoglobin. Data were subjected to one - way analysis of variance in completely randomized design (C.R.D.) as described by (Steel and Torrie ,1960) and SAS (2001) program were used in analysis data. Then by using Duncan's multiple range test at probability $(\mathrm{P} \leq 0.05)$ means were checked for statistical significance in different groups.

\section{RESULTS AND DISCUSSION}

Table (1) showed the effect of magnetic field exposing in live body weight, total weight gain and feed consumption. Statistical analysis of data indicates significant increase in live body weight and total weight gain for the treatments of exposing 30 and 90 mint. as compared with control and exposing $60 \mathrm{~min}$. No significant differences between treatments in feed consumption. This result was consist with (Mitre's , 2018 and Mahmoud et al., 2017).The significant increase in live body weight and weight gain may be due to that magnetic field affect thyroid gland by increase iodine which necessary for secretion( Ebrahim and Azab, 2017 and Mustafa,2019). Our results were in agreement with the result of (Mutter et al., 2019; Hassan et al .,2018 and Mahmoud et al., 2017). Table (2) indicate the effect of exposing breeders eggs to magnetic field in feed conversion ratio F.C.R., relative growth rate and production index. Statistical data analysis revealed no significance differences between feed conversion ratio treatments and relative growth rate. Important rise in therapy exposure to $30 \mathrm{~min}$. Compared with manufacturing index monitoring. 
Table (1): Effect of magnetic field exposing in live body weight (gm), Total Weight Gain (gm) and Feed Consumption(gm)

\begin{tabular}{|c|c|c|c|}
\hline $\begin{array}{c}\text { Treatments } \\
\text { Traits }\end{array}$ & $\begin{array}{c}\text { Live body weight } \\
\text { at 42 days }(\mathrm{gm})\end{array}$ & $\begin{array}{c}\text { Total Weight } \\
\text { Gain }(\mathrm{gm})\end{array}$ & $\begin{array}{c}\text { Feed Consumption } \\
(\mathrm{gm})\end{array}$ \\
\hline Control & $3397.7 \pm 39.14 \mathrm{~b}$ & $3352.4 \pm 38.94 \mathrm{~b}$ & $5630.6 \pm 17.85 \mathrm{a}$ \\
\hline Exposing 30 min & $3665.0 \pm 36.71 \mathrm{a}$ & $3618.1 \pm 36.71 \mathrm{a}$ & $5615.0 \pm 33.90 \mathrm{a}$ \\
\hline Exposing 60 min & $3381.7 \pm 36.48 \mathrm{~b}$ & $3411.0 \pm 33.70 \mathrm{~b}$ & $5554.0 \pm 33.12 \mathrm{a}$ \\
\hline Exposing 90 min & $3410.0 \pm 17.55 \mathrm{a}$ & $3659.7 \pm 31.66 \mathrm{a}$ & $5644.0 \pm 38.33 \mathrm{a}$ \\
\hline
\end{tabular}

Values with different letters vertically indicate significant differences at $(\mathrm{P} \leq 0.05)$.

The magnetic field 1800 Gauss.

This increasing may be due to the constant magnetic field exposure causing biochemical exchange that affect bio- metabolism (Santwan,2000), and agreed with the outcome of

$$
\text { (Mustafa,2008) }
$$

Table (2): Effect of magnetic field exposing in Feed Conversion Ratio (gm feed / gm weight), Relative Growth Rate \% and Production Index

\begin{tabular}{|c|c|c|c|}
\hline $\begin{array}{c}\text { Treatments } \\
\text { Traits }\end{array}$ & FCR & $\begin{array}{c}\text { Relative } \\
\text { Growth Rate }\end{array}$ & Production Index \\
\hline Control & $1.68 \pm 0.03 \mathrm{a}$ & $22.5 \pm 2.76 \mathrm{a}$ & $316.7 \pm 31.70 \mathrm{~b}$ \\
\hline Exposing 30 min & $1.55 \pm 0.04 \mathrm{a}$ & $24.7 \pm 1.94 \mathrm{a}$ & $384.8 \pm 30.73 \mathrm{a}$ \\
\hline Exposing 60 min & $1.66 \pm 0.04 \mathrm{a}$ & $25.2 \pm 1.48 \mathrm{a}$ & $341.9 \pm 48.28 \mathrm{ab}$ \\
\hline Exposing 90 min & $1.68 \pm 0.01 \mathrm{a}$ & $23.3 \pm 1.32 \mathrm{a}$ & $349.8 \pm 19.81 \mathrm{ab}$ \\
\hline
\end{tabular}

Values with different letters vertically indicate a significant difference at $(\mathrm{P} \leq 0.05)$.

The magnetic field 1800 Gauss.

Table (3) revealed the impact of magnetic field on fetal mortality, hatchability, mortality of chicks. Statistical data analysis showed that 30 minutes' magnetic exposer improve hatchability, fetal mortality and chick mortality. The increase in hatchability may be due to the reaction of bio metabolic cells between the central nervous system and the external magnetic field (Ebrahim and Azab, 2017). This results were in agreement with the results of (Zainal and Ibrahim, 2015; and Lotfi and Narimani-Rad, 2012). Table (4) Impact of magnetic field exposure in Dressing, Blood Glucose and Blood Hemoglobin Statistical data analysis shows a significant increase in treatment exposure to 30 minutes of Dressing and Blood Hemoglobin percentage and a significant decrease in blood glucose compared to control. This may be due to the change in the water molecule caused by the exposure of the egg to the magnetic field increased size and solubility as well as the ions in the water are affected, leading to a reduction in the content of free radicals (Ebrahim and Azab, 2017; and MTC, 2006). This result was agreement with the results of Mustafa (2008) who report to increase in dressing percentage in magnetic exposing as compared with control. 
Table (3): Effect of magnetic field exposing in Hatchability \%, Fetal Mortality \%, and Chicks Mortality \%

\begin{tabular}{|c|c|c|c|}
\hline $\begin{array}{c}\text { Treatments } \\
\text { Traits }\end{array}$ & $\begin{array}{c}\text { Hatchability } \\
\%\end{array}$ & $\begin{array}{c}\text { Fetal Mortality } \\
\%\end{array}$ & $\begin{array}{c}\text { Chicks Mortality } \\
\%\end{array}$ \\
\hline control & $80.0 \pm 1.45 \mathrm{~b}$ & $19.6 \pm 1.45 \mathrm{a}$ & $9.3 \pm 0.33 \mathrm{a}$ \\
\hline Exposing 30 min & $89.0 \pm 1.52 \mathrm{a}$ & $11.0 \pm 1.52 \mathrm{~b}$ & $2.6 \pm 0.33 \mathrm{~b}$ \\
\hline Exposing 60 min & $84.3 \pm 2.90 \mathrm{ab}$ & $15.6 \pm 2.90 \mathrm{ab}$ & $5.3 \pm 0.33 \mathrm{ab}$ \\
\hline Exposing 90 min & $83.0 \pm 2.30 \mathrm{ab}$ & $17.0 \pm 2.30 \mathrm{ab}$ & $6.6 \pm 0.33 \mathrm{ab}$ \\
\hline
\end{tabular}

Values with different letters vertically indicate a significant difference at $(\mathrm{P} \leq 0.05)$.

The magnetic field 1800 Gauss.

Table (4): Effect of magnetic field exposing in Dressing percentage \%, Blood glucose ( $\mathrm{mg} / \mathrm{dl}$ ) and Blood Hemoglobin $\mathrm{Hb}$ (gm /100 ml blood)

\begin{tabular}{|c|c|c|c|}
\hline $\begin{array}{c}\text { Treatments } \\
\text { Traits }\end{array}$ & $\begin{array}{c}\text { Dressing } \\
\text { percentage }\end{array}$ & $\begin{array}{c}\text { Blood glucose } \\
(\mathrm{mg} / \mathrm{dl})\end{array}$ & $\begin{array}{c}\mathrm{Hb} \\
(\mathrm{gm} / 100 \mathrm{ml} \text { blood }\end{array}$ \\
\hline control & $75.0 \pm 1.95 \mathrm{~b}$ & $176.0 \pm 2.30 \mathrm{a}$ & $7.4 \pm 0.15 \mathrm{~b}$ \\
\hline Exposing 30 min & $80.5 \pm 0.41 \mathrm{a}$ & $186.3 \pm 2.33 \mathrm{a}$ & $8.1 \pm 0.17 \mathrm{a}$ \\
\hline Exposing 60 min & $78.1 \pm 0.88 \mathrm{ab}$ & $176.0 \pm 4.72 \mathrm{a}$ & $7.6 \pm 0.21 \mathrm{ab}$ \\
\hline Exposing 90 min & $78.2 \pm 0.86 \mathrm{ab}$ & $176.3 \pm 3.48 \mathrm{a}$ & $7.8 \pm 0.11 \mathrm{ab}$ \\
\hline
\end{tabular}

Values with different letters vertically indicate a significant difference at $(\mathrm{P} \leq 0.05)$.

The magnetic field 1800 Gauss.

Table (5) Effect of magnetic field exposing in total red blood cell count R.B.C, total count of white blood cells W.B.C., packed cell volume (PCV). Statistical analysis of data showed a significant increase in R.B.C. P.C.V and W.B.C. in 30 mit. magnetic exposed group as compared with as compared with control and 90 Min magnetic exposed group. This result was in agreement with the results of (Mutter et al., 2019; Zawlak et al., 2018 and Al-Hilali,2018) whom reported that there was an improving in most blood traits in magnetic treatments as compared with control.

Table (5): Effect of magnetic field exposing in total red blood cell count R.B.C.(million cells $/ \mathrm{mm}^{3}$ blood), the total count of white blood cells W.B.C. (Thousands cells $/ \mathrm{mm}^{3}$ blood) and Packed Cell Volume (P.C.V)\%

\begin{tabular}{|c|c|c|c|}
\hline Treatments & $\begin{array}{c}\text { R.B.C. } \\
\text { Trillion cells } / \mathrm{mm}^{3} \\
\text { blood) }\end{array}$ & $\begin{array}{c}\text { W.B.C. } \\
\text { (Thousands cells } / \mathrm{mm}^{3} \\
\text { blood) }\end{array}$ & $\begin{array}{c}\text { P.C.V. } \\
\%\end{array}$ \\
\hline Control & $2.47 \pm 0.03 \mathrm{~b}$ & $26.18 \pm 0.39 \mathrm{~b}$ & $26.0 \pm 0.57 \mathrm{~b}$ \\
\hline Exposing $30 \mathrm{~min}$ & $2.70 \pm 0.09 \mathrm{a}$ & $27.84 \pm 0.25 \mathrm{a}$ & $28.3 \pm 0.33 \mathrm{a}$ \\
\hline Exposing 60 min & $2.53 \pm 0.07 \mathrm{ab}$ & $26.91 \pm 0.10 \mathrm{ab}$ & $27.0 \pm 0.03 \mathrm{ab}$ \\
\hline Exposing 90 min & $2.53 \pm 0.04 \mathrm{ab}$ & $26.98 \pm 0.42 \mathrm{ab}$ & $26.6 \pm 0.33 \mathrm{~b}$ \\
\hline
\end{tabular}

Values with different letters vertically indicate a significant difference at $(\mathrm{P} \leq 0.05)$.

The magnetic field 1800 Gauss. 


\title{
تأثير تعريض بيض امهات اللحم للمجال المغناطيسي قصير المدى في الفقس والاداء الانتاجي للنسل الناتج
}

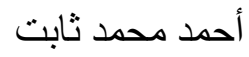 \\ دريد ذنون يونس \\ قسم الانتاج الحيو اني / كلية الزر اعة و الغابات / جامعة الموصل / العراق \\ Email dr.duraid@uomosul.edu.iq
}

\begin{abstract}
الخلاصة
هدفت هذه الدراسة لمعرفة تأثير تعريض بيض أمهات دجاج اللحم للمجال المغناطيسي قبل الفقس على الفقس والاداء الانتاجي للنسل الناتج. أستخدم في هذه الدراسة ثلاثمائة بيضة مخصبة منتجة من امهات روز 380 تم تقسيمها الى أربعة معاملات (خمس وسبعون بيضة لكل معاملة). وكانت المعاملات كالاتي: ألمعاملة الاولى ملى الماته

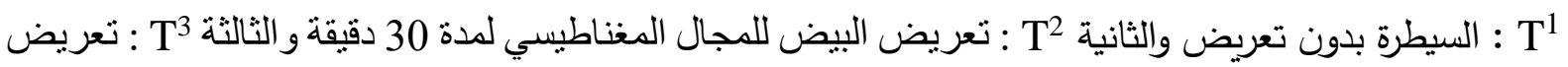
البيض للمجال المغناطيسي لمدة 60 دقيقة والرابعة T $^{4}$ : تعريض البيض للمجال المغناطيسي لمدة 90 دقيقة. وكان التعريض قبل وضع البيض في المفقسة وان شدة المجال المغناطيسي Gauss 1800 . وبعد الفقس ربيت الافراخ الفاقسة في قاعة من النوع نصف المفتوح ووفرت جميع الظروف البيئية اللازمة واستمرت التربية لغاية عمر 42 يوم. أظهرت نتائج التحليل الاحصائي ان تعريض بيض التفقيس للمجال المغناطيسي لمدة 30 دقيقة أدى الى لى زيادة معنوية (أح>05.05) في نسبة الفقس، وزن الجسم الحي، الزيادة الوزنية الكلية، نسبة التصافي، الدليل الانتاجي، العدد التفريقي لكل من .P.C.V. ،R.B.C. ،W.B.C، وهيموكلوبين الدم وكلوكوز الدم. وانخفاض معنوي في نسبة الهلاكات الجنينية وهلاكات الافراخ. وعدم وجود فروقات معنوية بين المعاملات في معامل التحويل الغذائي ومعدل النمو النسبي واستهلاك العلف. الكلمات المفتاحية: المجال المغناطيسي، بيض الامهات، الفقس، الاداء الانتاجي.
\end{abstract}

$$
\text { تاريخ تسلم البحث: } 10 \text { / } 12 \text { / 2020، وقبوله : } 13 \text { / } 3 \text { / } 2021
$$

\section{REFERENCES}

Al-Hilali, A.H. (2018). Effect of magnetically treated water on physiological and biochemical blood parameters of Japanese quail. International Journal of Poultry Science. 17 (2),78-84.

Al-Mosely, M.A. (2013). Magnetic Water. Arabic edition. Al-Yazouri Scientific House for Publishing and Distribution. Amman Jordan.P:90-91.

Anonymous (2001). SAS User Guide: Statistics Version 6th ed. SAS Institute

Duncan, D.B. (1955). Multiple Range and Multiple F-test Biometrics.

Ebrahim, S.A., \& Azab, E.A. (2017). Biological effect of magnetic water on human and animals. Biomedical Sciences. 3(4), 78-85.

Hassan, S., Youssef, S., Attia, A., El-Sheikh, A.M., \& Abdelkader, A.M. (2018). Productive, egg quality and physiological responses of gimmizah chicken as affected by magnetized water of different strengths. Egyptian Poultry Science, 38 (1), 51-64. 
Lotfi, A., \& Narimani-Rad, M. (2012). Effect of exposure to extremely low frequency electromagnetic fields $(50 \mathrm{~Hz}, 0.5 \mathrm{mT})$ During Incubation on Hatchability, T3 and T4 Levels in Newly-hatched Chicks. Asian Journal of Animal and Veterinary Advances, 7 (8), 733-738.

Mahmoud, M. S. H., Soliman, F.N.K. Bahie EL Deen .M \& EL-Sebai, A. (2017). Effect of magnetic drinking water, feed form and it's restricted on Sasso broilers .I. Productive performance. Egyptian Poultry Science. 37, 1069-1082.

Mitre, K. (2018). The Effect of Magnetic Water on Feed Conversion Ratio, Body Weight Gain, Feed Intake and Livability of Male Broiler Chickens. Dale Bumpers College of Agriculture, Food and Life Sciences. University of Arkansas P : 10-11.

MTC, (2006). Biological and Therapeutic Functions of Magnetized Water. Magnetic Therapy Learning Center. (www. magnetictherapyfact.org).

Mustafa, M. A. (2019). Application of magnetic technology in local quail house and hatchery on performance, reproductive and physiological traits under heat stress. Iraqi Journal of Veterinary Sciences, 33(2), 259-266.

Mustafa, N. A. (2008). Effect of Magnetic Water in Embryonic Development of Hatched Eggs and Reproductive and Physiological Performance of Two Commercial Broiler Hybrid . M.Sc. Thesis. University of Mosul P: 63-65.

Mutter, A. Z., Almayahi, M., \& Jader, M.M. (2019). Effect of three type of drinking water on performance and some of blood parameter of broiler chicks. Basra journal veterinary research ,18 (1),380-390.

Pawlak, K., B. Bojarski, Z. Nieckarz, M. Wojnar, L.T. (2018). Effect of an $1800 \mathrm{MHz}$ electromagnetic field emitted during embryogenesis on the blood picture of oneday-old domestic hen chicks (Gallus gallus domesticus). Acta Veterinaria Brno, 87,65-71.

Remedy, M.(2006).Drinking Magnetized Water . (suzmags@magneticremedy.com )

Rokicki , R. (2006). Magnetic Fields and Electropolished Metallic Implants. Medical Device and Diagnostic Industry. (info@electrobright.com)

Santwani, M. T. ( 2000) . How a Magnet Heals-Similarity with Electro-Therapy. The Source for Alternative Medicines and Holistic Healthy. Indian gyan.com. B Jain Publishers Pvt Ltd, India P :163.

Tischler, M. (2003). The Magic of Magnets. The Science Instruments company and bio magnetics International. Textbook. Springer Gabler :381.

Young, I. C. and Lee. (2005). Reduction in the surface tension of water due to physical water treatment for fouling control in heat exchangers. International Communications in Heat and Mass transfer. 32, 1 - 9. (Abstract).

Zainal O.A. and Ibrahim M. I. (2015). The Effect of Exposing the Eggs Mothers of Broiler Chickens Magnetic Field before Incubation on Embryonic Development and Some Hatching Traits of Broiler Chicks. M.Sc. Thesis. University of Mosul.59-60. 